\title{
Effects of Liquid Wastes from Tofu Industries on Water Quality in Parangan River, Magelang District, Central Java-Indonesia
}

\author{
Wiwik Widyaningrum $^{1}$ and Margaretha Widyastuti $^{1 *}$ \\ ${ }^{1}$ Department of Environmental Geography, Faculty of Geography, Universitas Gadjah Mada, 55281 Yogyakarta Special Region \\ Indonesia
}

\begin{abstract}
Continued entries of liquid wastes generated by tofu industries into nearby rivers might deteriorate the water quality if disposed of without prior treatments. The research objectives were to determine the liquid waste quality from tofu productions near Parangan River (Magelang, Indonesia), assess the river water quality and investigate the effects of the liquid waste on pollution load and water quality status. With this information, the research can help determine pollutant load allocation in the river and provide the basis for formulating water quality management policies if it is not contaminated or pollution controls if otherwise. This research employed purposive sampling, direct measurements in the field, laboratory tests, descriptive-comparative analysis, mass balance and pollution index method. The results showed that the $\mathrm{pH}$, temperature, $\mathrm{COD}, \mathrm{BOD}$, TSS and ammonia levels of the liquid wastes had surpassed their maximum permissible levels. Similarly, the river's COD, BOD and ammonia contents did not meet the water quality standards. With BOD, a pollution load indicator, exceeding the total maximum daily load, the water quality statuses at monitoring points S2, S3 and S4 were categorised into slightly polluted. It means that the liquid waste generated by the tofu industries has detrimental effects on the water quality of the Parangan River.
\end{abstract}

\section{Introduction}

Water is a natural resource that is utilised vastly to meet the basic needs of living organisms worldwide. Without good management, damages to sources of extractable water like decreased quality are inevitable. Water quality measures the suitability of a water body for a particular designated use based on physical, chemical and biological parameters [1]. In this context, pollution occurs when parameter values or classes do not meet the applicable water quality standards. Quality, among other factors, determines if and to what extent a source can sustain its function and intended use.

Industrial activity is among the crucial components in meeting the economic needs of a community [2]. On the other hand, it is also one of the leading causes of water pollution due to the waste produced. In Magelang District, Indonesia ${ }^{1}$, tofu industries are small-scale enterprises that have yet to incorporate liquid waste treatment prior to disposal into production costs. This liquid waste contains high pollutants and suspended and dissolved solids that experience physical, chemical and biological changes [3]. With these characteristics, it will substantially reduce the water quality if discarded directly into the river and lead to decreased productivity, environmental capacity and carrying capacity of the river water [23].

Candimulyo and Tegalrejo Sub-districts are the centres of tofu industries in the Magelang District. The factories have formed a linear pattern following the Parangan River channel, which somehow facilitates direct waste disposal to the water body. Each has a pipeline or an outlet that drains into the nearby channel. As a result, the local community no longer uses or extracts water from the river because the tofu industry

\footnotetext{
*Corresponding author: mwiwik@ugm.ac.id
}

has made it the dumpsite for the liquid waste byproducts.

This area was selected because the tofu industry did not pre-treat the liquid waste before disposal of to the river. If left unchecked, this practice can reduce the water quality. Further, there has not been a study focusing on this issue on the Parangan River. Therefore, this research was designed to assess the liquid waste quality generated by the tofu industry based on Provincial Regulation of Central Java Number 5 of 2012, analyse the river water quality per the class II water standards in the Government Regulation Number 82 of 2001 and investigate the pollution load and water quality status of the Parangan River.

\section{Research Method}

The tools and materials used in this study were Avenza maps, sample bottles, water checkers, ranging poles, cooler boxes, measuring tapes, Abney level, camera, research checklist, plastic strings, labels, stationery and distilled water.

The sampling points for liquid waste were selected by purposive sampling that considered the scale of tofu production. The amount of soybean used was divided using standard deviation classification into three scales of production: low, medium and high. The river water sampling time was also determined by purposive sampling that factored in the time of day when the liquid waste was discarded. Here, the water collection referred to the surface water sampling methods issued in SNI 6989-57-2008

The river water for the quality analysis was sampled at four points: S1, S2, S3 and S4. S1 represents the river segment upstream of the liquid waste outlets. S2 marks the river segment where the liquid waste starts to mix with the river water, while $\mathrm{S} 3$ receives a significant input of the liquid waste. S4 is located at the outlet of the 
Parangan River. The river water sampling locations in this study are shown in a map in Fig. 1.

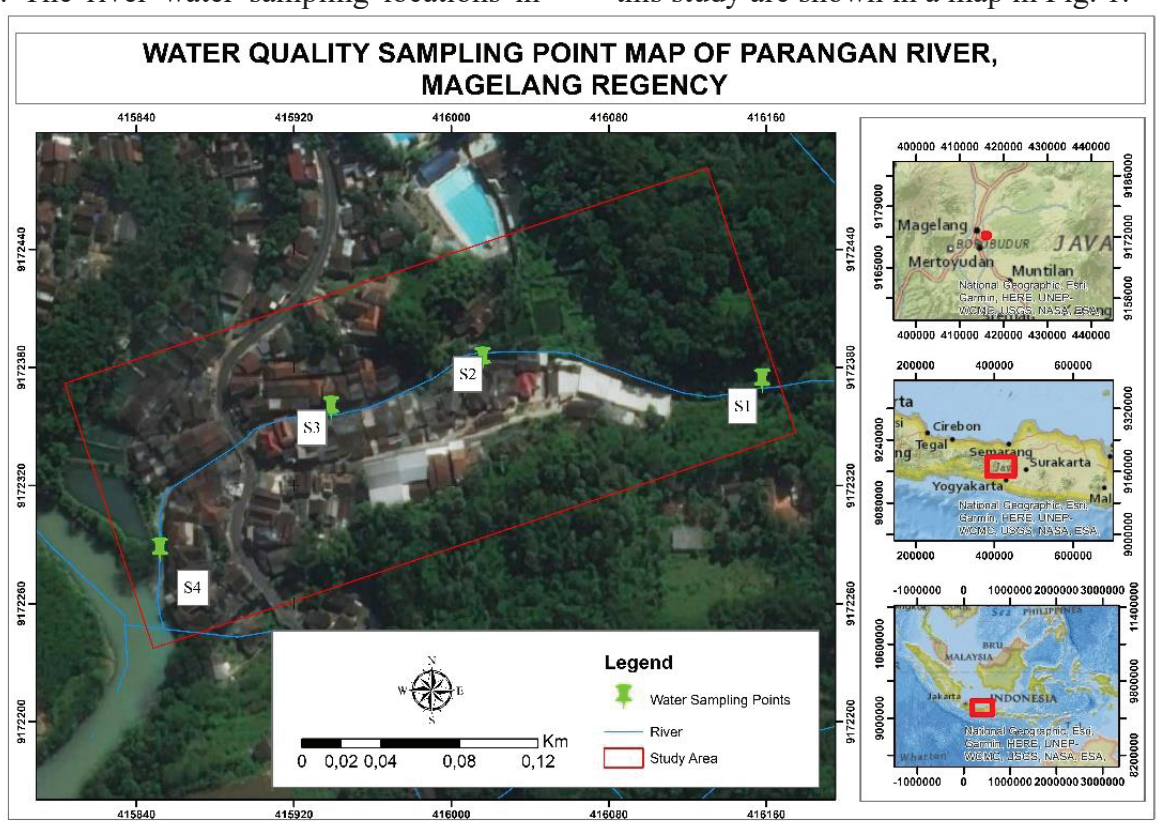

Fig. 1. Map of the four water sampling points in the Parangan River

The water samples were collected twice at different times by taking into account the water travel time in river channels. According to $[4,5]$, water travel time, $T$ (in minutes), is a function of river length, $L(\mathrm{~m})$, and flow velocity, $V(\mathrm{~m} / \mathrm{s})$, or as presented in Eq. 1 below.

$$
\mathrm{L}=\mathrm{T} / 60 \mathrm{~V}
$$

The discharge was measured directly in the field using the slope area method because the river had rocky beds. The general discharge formula, $Q\left(\mathrm{~m}^{3} / \mathrm{s}\right)$, is flow velocity, $V(\mathrm{~m} / \mathrm{s})$, times the wet cross-sectional area, $A\left(\mathrm{~m}^{2}\right)$, or as presented in Eq. 2 below.

$$
\mathrm{Q}=\mathrm{A} \times \mathrm{V}
$$

Data on the liquid waste and river water qualities, including temperature, colour, odour, $\mathrm{pH}$ and electrical conductivity (EC), were measured directly in the field using a water checker. Meanwhile, other parameters like total suspended solids (TSS), chemical oxygen demand (COD), biological oxygen demand (BOD), ammonia $\left(\mathrm{NH}_{3}-\mathrm{N}\right)$ and dissolved oxygen (DO) were tested in the laboratory (Table 1). Before the laboratory analyses, the samples were preserved by cooling to suppress physical, chemical and biological changes.

Table 1. The water sample analysis methods in the laboratory

\begin{tabular}{ll}
\multicolumn{1}{c}{ Parameters } & \multicolumn{1}{c}{ Test Methods } \\
\hline COD & SNI 6989.2-2019 \\
\hline BOD & SNI 6989.72-2009 \\
\hline TSS & In-house method \\
\hline NH $_{3}-\mathbf{N}$ & SNI 06-6989.30-2005 \\
\hline DO & APHA 2017, section 4500-OG \\
\hline
\end{tabular}

The parameter values were analysed descriptively and compared with the quality standards, namely
Provincial Regulation Number 5 of 2012 for the liquid waste [6] and Government Regulation Number 82 of 2001 for the river water designated for class II purposes, e.g., water recreation infrastructure/facilities, freshwater aquaculture, livestock farming and agricultural irrigation [7]. The pollution load was calculated with the mass balance method using the formula in Eq. 3. The mean constituent concentration of the combined flow, $C R$, is a function of the constituent concentration in the $i$-th flow, $\mathrm{Ci}$, and the discharge of the $i$-th flow, $Q i$. CR is also the constituent mass in the $i$-th flow, $M i$, divided by $Q i$

$$
C R=\frac{\sum C i Q i}{\sum Q i}=\frac{\sum M i}{\sum Q i}
$$

The river water quality status was determined based on the Pollution Index (PI) according to the Decree of Minister of Environment Number 115 of 2003 using Eq. 4 below

$$
P i j=\sqrt{\frac{(C i / L i j)^{2} M+(C i / L i j)^{2} R}{2}}
$$

$P i j$ is the pollution index for the water designation $j, C i$ is the concentration or value of the water quality parameter $i, L i j$ is the concentration or value of the water quality parameter listed in the quality standard for the water designation $j,(\mathrm{Ci} / L i j) M$ is the maximum value of $C i / L i j$ and $(C i / L i j) R$ is the average value of Ci/Lij. 


\section{Results and Discussion}

\subsection{Centre of Tofu Industry Activities}

There are 42 home-based small-scale tofu producers on the north and south sides of the Parangan River (Fig.
2). Each operates 29 days a month and processes, on average, $400-500 \mathrm{~kg}$ of soybeans per day. This industrial activity has been running for decades.

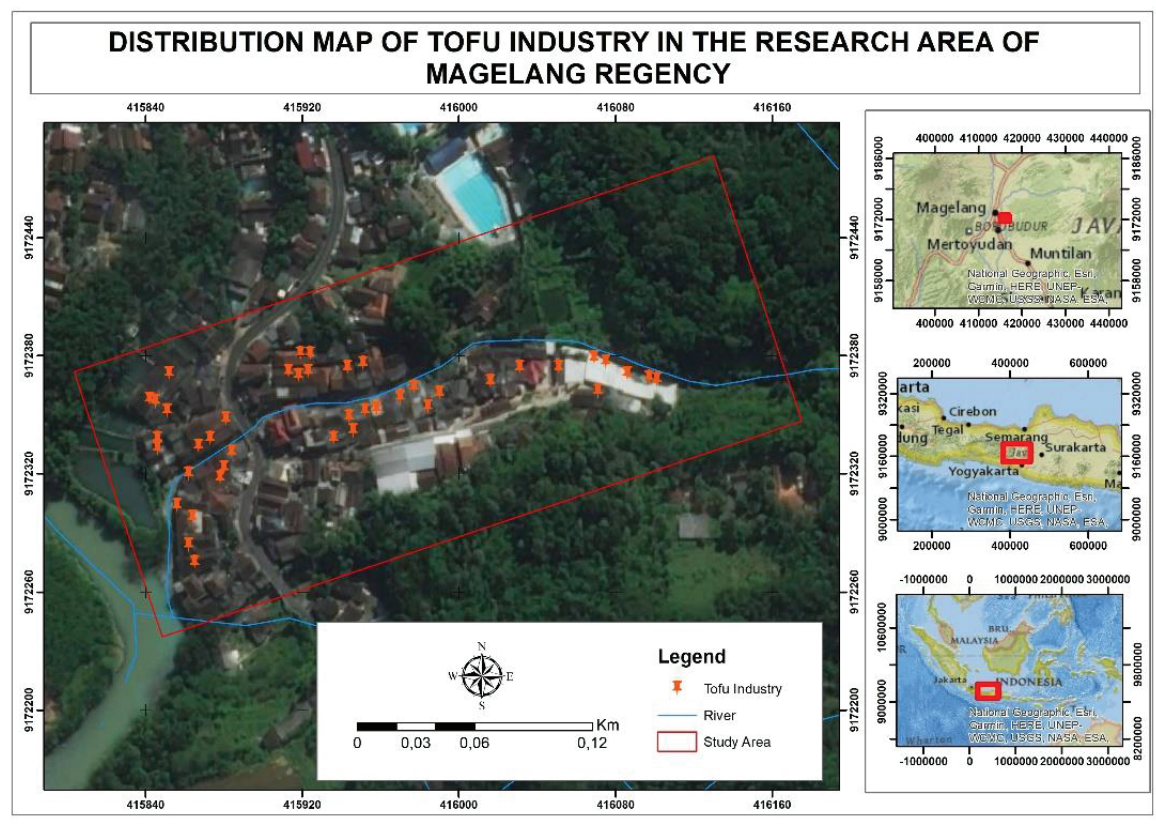

Fig. 2. Distribution map of the tofu producers on the south and north sides of the Parangan River, Magelang District

Only four tofu producers drained their waste byproducts into fish ponds as treatment facilities before the treated waste flowed into the Parangan River through the pond outlets. Most others disposed of the liquid waste directly to the river. Based on the interview results, the latter was dominant because there was no space left to build the wastewater treatment plant (WWTP) and the presumption that the liquid waste would not contaminate the river and that after all this water body would continuously flow.

\subsection{Liquid Waste Quality}

In this research, the liquid waste quality parameters were measured in the field and from the samples collected during three different scales of production, namely low, medium and high. The measured temperatures varied between 43.2 and $47.1^{\circ} \mathrm{C}$ (Fig. 3) or were above the upper limit value in the quality standard, $38^{\circ} \mathrm{C}$ [6]. The entry of waste with high temperatures into the water will interfere with the growth of aquatic biota [8].

The $\mathrm{pH}$ values were in the range of 3.53-4.67 (Fig. 4) and did not meet the quality standard, namely 6-9 [6]. This acidic waste is believed to have originated in the vinegar used in tofu making, especially the clumping and soaking process [8].

The liquid waste samples were turbid, yellow fluid with white suspension and a pungent smell (Table 2). The strong odour is caused by volatile substances released from the fluid [9].

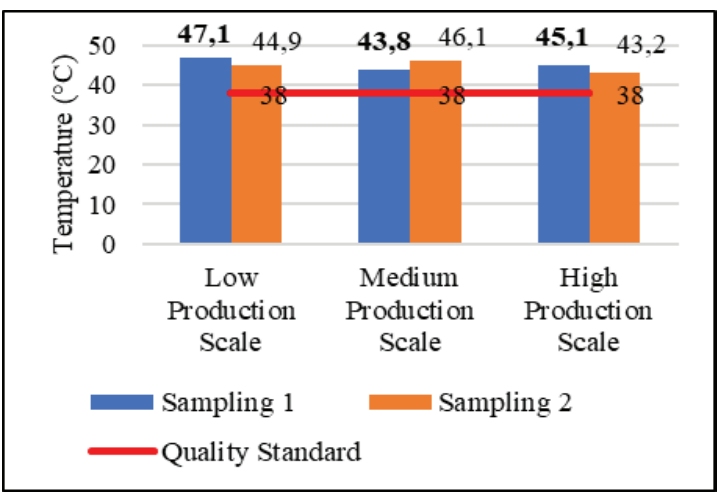

Fig. 3. Temperatures of the liquid waste by-products of the tofu industry during low, medium and high production scales

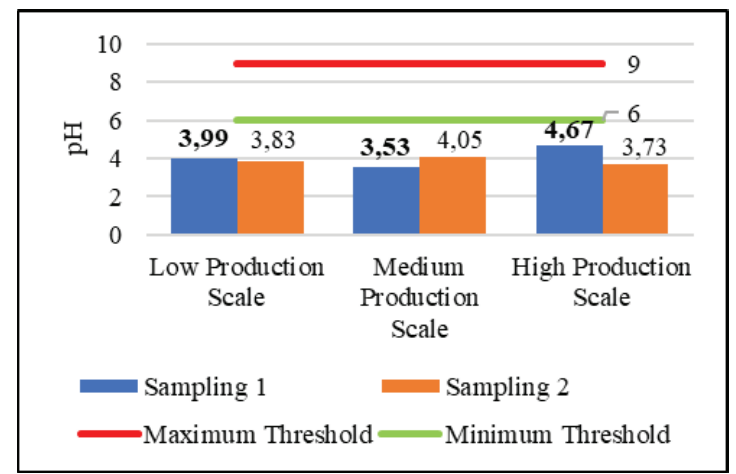

Fig. 4. $\mathrm{pH}$ values of the liquid waste by-products of the tofu industry during low, medium and high production scales 
Table 2. The colours and odours of the liquid waste byproducts of the tofu industry during low, medium and high production scales

\begin{tabular}{lllll}
\hline Production & \multicolumn{2}{c}{ Sample 1 } & \multicolumn{2}{c}{ Sample 2 } \\
\cline { 2 - 5 } Scales & Colours & Odours & Colours & Odours \\
\hline Low & Turbid, & Pungent & \multicolumn{1}{c}{$\begin{array}{l}\text { Turbid, } \\
\text { yellow }\end{array}$} & Pungent \\
& yellow & & & \\
\hline \multirow{2}{*}{ Medium } & Turbid, & Pungent & $\begin{array}{l}\text { Turbid, } \\
\text { yellow }\end{array}$ & Pungent \\
& yellow & & yellow & \\
\hline High & Turbid, & Pungent & Turbid, & Pungent \\
& yellow & & yellow & \\
\hline
\end{tabular}

Electrical conductivity (EC) describes the total concentrations of the dissolved ions in water. The EC values of the samples varied from 1508 to $1726 \mu \mathrm{s} / \mathrm{cm}$ (Fig. 5). The highest EC, $1.726 \mu \mathrm{s} / \mathrm{cm}$, was detected during high production. High EC occurs when large amounts of elements are dissolved in the water.

In general, the samples had very high Chemical Oxygen Demand (COD), i.e., 7150-8850 mg/L (Fig. $6)$. This range far exceeded the maximum permissible level of COD in the quality standard, $275 \mathrm{mg} / \mathrm{L}$ [6]. In this case high COD is attributable to the presence of high organic compounds that are barely decomposed by microorganisms [10].

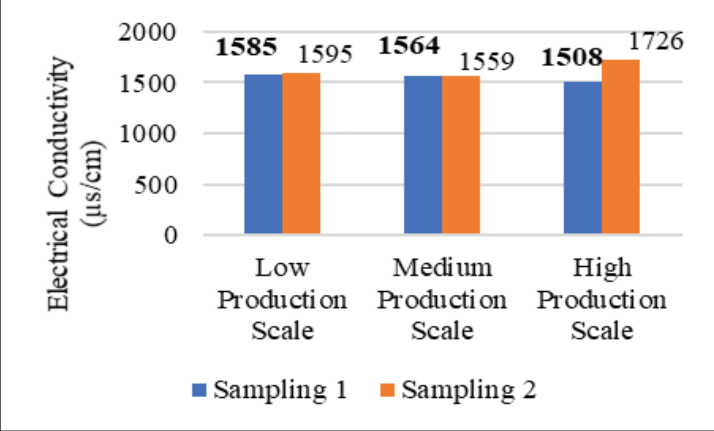

Fig. 5. Electrical conductivities of the liquid waste byproducts of the tofu industry during low, medium and high production scales

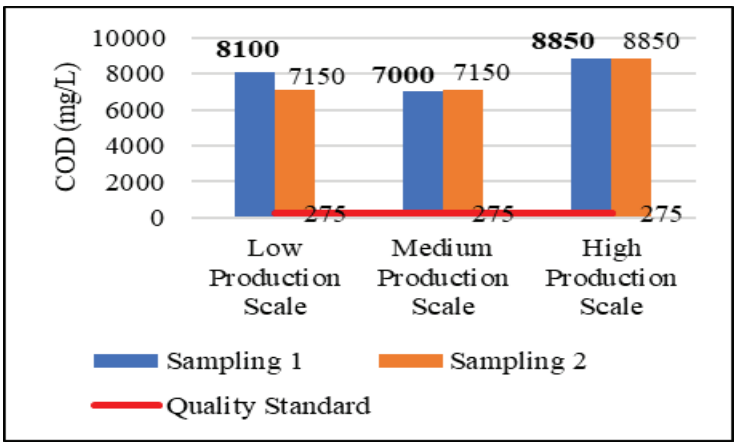

Fig. 6. Chemical oxygen demands (COD) of the liquid waste by-products of the tofu industry during low, medium and high production scales

The samples also had varying levels of Biochemical Oxygen Demand (BOD), i.e., 4880-6810 mg/L (Fig. 7), that did not meet the quality standard, $150 \mathrm{mg} / \mathrm{L} \mathrm{[6].}$ The high BOD is caused by the high protein contained in the liquid waste, which is $40-60 \%$ of the raw material used in tofu making [11].

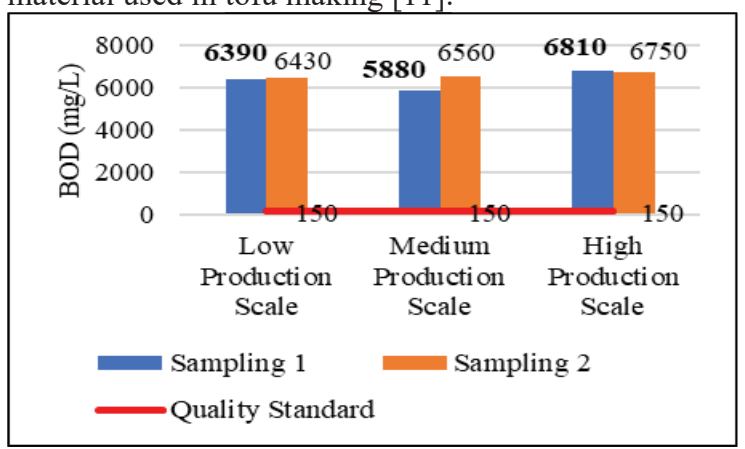

Fig. 7. Biochemical oxygen demands (BOD) of the liquid waste by-products of the tofu industry during low, medium and high production scales

Total Suspended Solid (TSS) in all samples varied between 1100 and $3280 \mathrm{mg} / \mathrm{L}$ (Fig. 8), exceeding its upper limit value, $100 \mathrm{mg} / \mathrm{L} \mathrm{[6]}$. The high TSS is believed to be the result of solid residues (soybeans) suspended in the liquid waste. TSS closely correlates with turbidity: the higher the TSS, the more turbid the water [1].

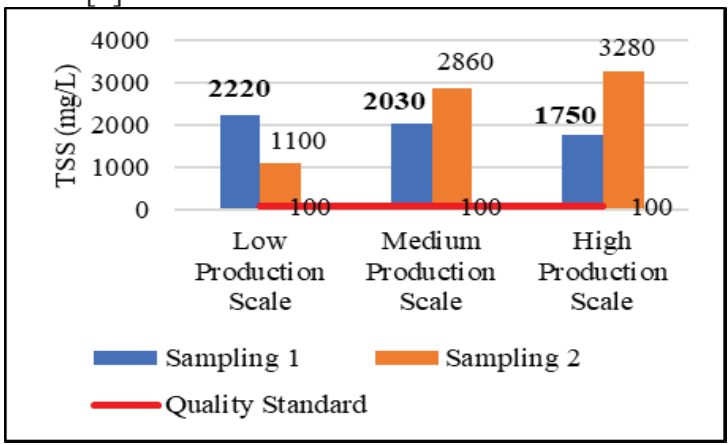

Fig. 8. Total suspended solids (TSS) of the liquid waste byproducts of the tofu industry during low, medium and high production scales

The liquid waste generated by the tofu industry also contains ammonia, which comes from the anaerobic digestion of nitrogen [1]. The samples showed 0.1390 to $5.9987 \mathrm{mg} / \mathrm{L}$ of $\mathrm{NH}_{3}-\mathrm{N}$ (Fig. 9), with the highest $\mathrm{NH}_{3}-\mathrm{N}$ found in the first sample of the medium production scale. The high $\mathrm{NH}_{3}-\mathrm{N}$ level is responsible for the foul smell of the liquid waste [12].

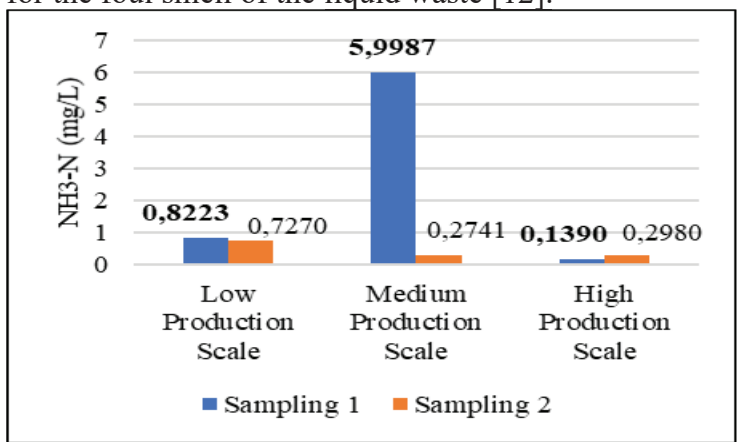

Fig. 9. Total ammonia contents $\left(\mathrm{NH}_{3}-\mathrm{N}\right)$ of the liquid waste by-products of the tofu industry during low, medium and high production scales 
Overall, the temperature, $\mathrm{pH}, \mathrm{COD}, \mathrm{BOD}, \mathrm{TSS}$ and $\mathrm{NH}_{3}-\mathrm{N}$ of the samples measured and collected during low, medium and high production scales have exceeded their upper limit values in the quality standards [6]. Also, it was found that each parameter varies in levels and values, but this does not depend on the tofu production scale. In other words, the production scale does not affect the quality of the liquid waste by-products. However, suppose any liquid waste with parameter values exceeding their maximum permissible levels is discarded without proper treatments. Then, many environmental problems may arise from increased water turbidity, high organic matter, low DO, pathogenic bacterial growth and unpleasant odour [19].

\subsection{River Water Quality}

The temperatures were measured directly in the field, and the readings showed a variation between 26.3 and $27.2^{\circ} \mathrm{C}$ (Fig. 10). Aquatic organisms grow and metabolise optimally at $25-30^{\circ} \mathrm{C}$ [17]. This means that the river water temperature still meets the class II water quality standards, namely a deviation of $3^{\circ} \mathrm{C}$ from nature's temperature [7]. The two samples collected at $\mathrm{S} 4$ showed the highest temperature.

A water body normally has $\mathrm{pH}$ 6-9 and most aquatic biotas prefer $\mathrm{pH} 7-8.5$ [1]. Measurements at four sampling points showed that the river's $\mathrm{pH}$ ranged from 6.52 to 7.22 (Fig. 11), which is still within the acceptable $\mathrm{pH}$ for class II water and meets the requirements for the growth of fish and aquatic biota $[2,7]$. Low $\mathrm{pH}$ can reduce dissolved oxygen levels and cause the death of aquatic biota [18].

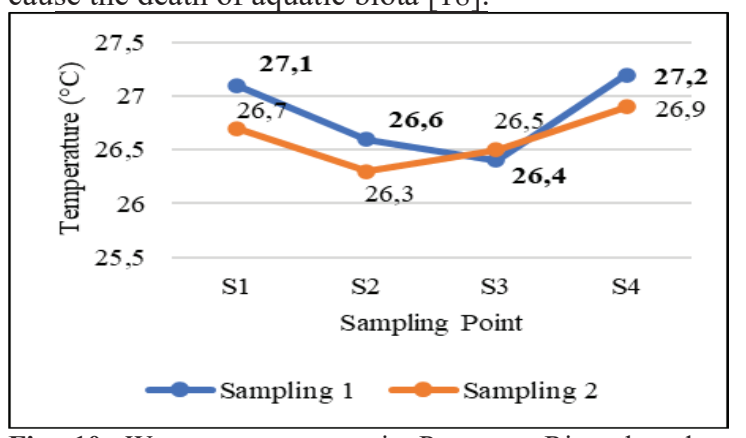

Fig. 10. Water temperatures in Parangan River based on direct measurements at four sampling points (in duplicate)

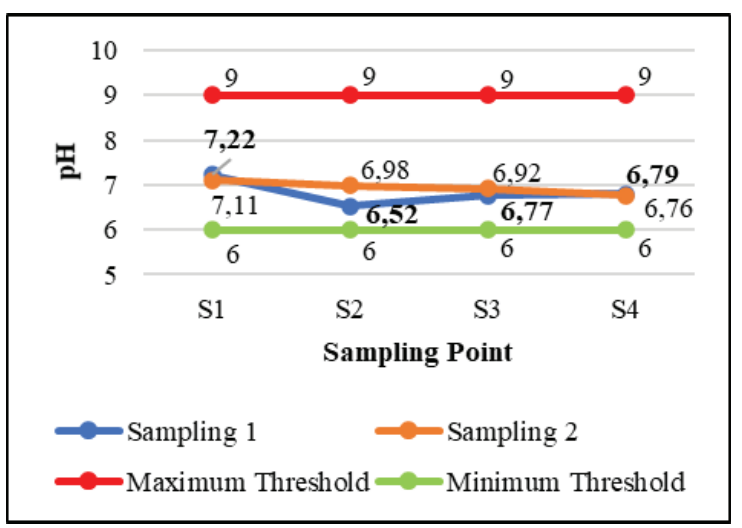

Fig. 11. Water $\mathrm{pH}$ in Parangan River based on direct measurements at four sampling points (in duplicate)
Colours and odours are two physical parameters observed directly in the field. At all observation/ sampling points, the water in Parangan River had a slightly turbid, grey colour and non-pungent smell (Table 3 ). The slightly turbid colour is caused by the entry of the liquid waste.

Table 3. Water colours and odours in Parangan River based on direct measurements at four sampling points (in duplicate)

\begin{tabular}{cllll}
\hline $\begin{array}{c}\text { Sampling } \\
\text { Points }\end{array}$ & \multicolumn{2}{c}{ Sample 1 } & \multicolumn{2}{c}{ Sample 2 } \\
\cline { 2 - 5 } S1 & Colours & Odours & \multicolumn{1}{c}{ Colours } & Odours \\
\hline S2 & $\begin{array}{l}\text { Not } \\
\text { pungent }\end{array}$ & Clear & $\begin{array}{l}\text { Not } \\
\text { pungent }\end{array}$ \\
\hline slight brown, & $\begin{array}{l}\text { Not } \\
\text { pungent }\end{array}$ & $\begin{array}{l}\text { Light brown, } \\
\text { slightly turbid }\end{array}$ & $\begin{array}{l}\text { Not } \\
\text { pungent }\end{array}$ \\
\hline S3 & $\begin{array}{l}\text { Grey, slightly } \\
\text { turbid }\end{array}$ & $\begin{array}{l}\text { Not } \\
\text { pungent }\end{array}$ & $\begin{array}{l}\text { Grey, slightly } \\
\text { turbid }\end{array}$ & $\begin{array}{l}\text { Not } \\
\text { pungent }\end{array}$ \\
\hline S4 & $\begin{array}{l}\text { Grey, slightly } \\
\text { turbid }\end{array}$ & $\begin{array}{l}\text { Not } \\
\text { pungent }\end{array}$ & $\begin{array}{l}\text { Grey, slightly } \\
\text { turbid }\end{array}$ & $\begin{array}{l}\text { Not } \\
\text { pungent }\end{array}$ \\
\hline
\end{tabular}

In natural waters, the electrical conductivities (EC) are normally in the range of $20-1500 \mu \mathrm{s} / \mathrm{cm}$ [13]. The measurement results showed that the EC values of the river did not vary widely, i.e., 200-233 $\mu \mathrm{s} / \mathrm{cm}$ (Fig. 12 ), and were relatively low because the measurement was conducted in the rainy season. Water bodies in areas with high rainfall intensity are known to have low EC [14]. Government Regulation Number 82 of 2001 does not include the lower or upper limit values for EC in rivers designated for class II purposes [7].

Chemical oxygen demand (COD) describes the amount of oxygen required to oxidise organic matter chemically. In waters organic matters can occur naturally or come from household and industrial activities [1]. The laboratory analysis results showed that the COD levels of the samples were in the range of 14.3-33 mg/L (Fig. 13). Based on class II water quality standards [7], the maximum allowable COD is 25 $\mathrm{mg} / \mathrm{L}$. This limit was exceeded at two sampling points, namely S2 and S4, with COD of $33 \mathrm{mg} / \mathrm{L}$ and 25.4 $\mathrm{mg} / \mathrm{L}$, respectively. Higher COD indicates that the waste contains greater concentrations of organic matter and the river experiences severer pollution $[11,18]$.

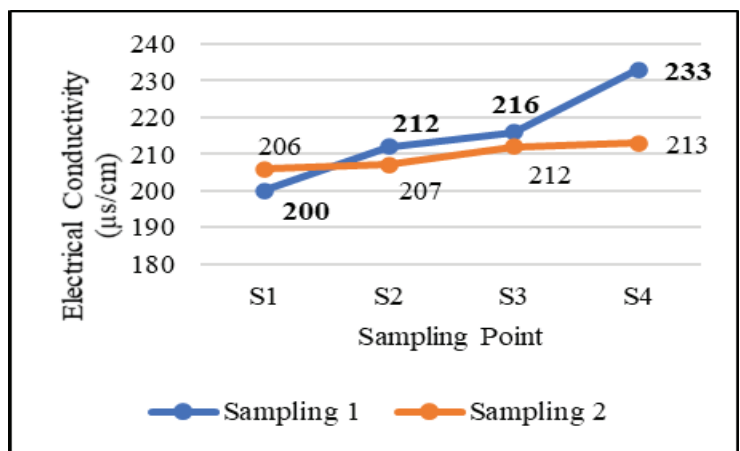

Fig. 12. Electrical conductivities in Parangan River based on direct measurements at four sampling points (in duplicate) 


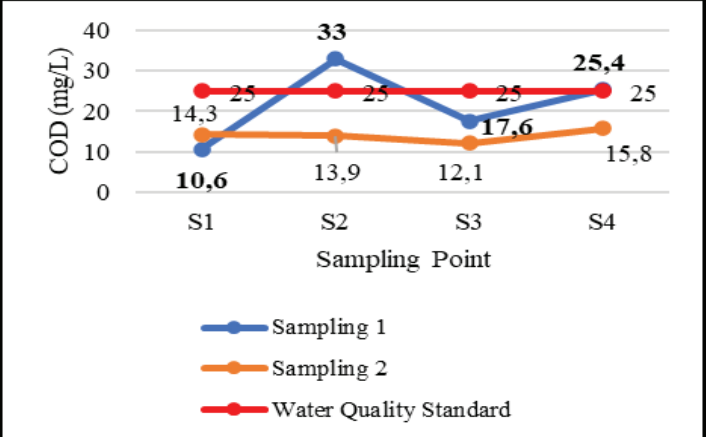

Fig. 13. Chemical oxygen demands (CODs) in Parangan River based on the laboratory analysis of samples collected in duplicate at four sampling points

Biochemical oxygen demands (BODs) describe the amount of oxygen that aerobic microbes require to oxidise organic matter [1]. In Parangan River, the BODs ranged from 1 to $7.8 \mathrm{mg} / \mathrm{L}$ (Fig.14). Based on the quality standards [7], all samples have higher BOD than the maximum permissible level, $3 \mathrm{mg} / \mathrm{L}$, except for S1 or upstream of the liquid waste outlet. The high BOD is attributable to the entry of liquid waste from the tofu industry that contains a substantial amount of organic matter. Higher BOD indicates a higher presence of organic matter in a water body [15].

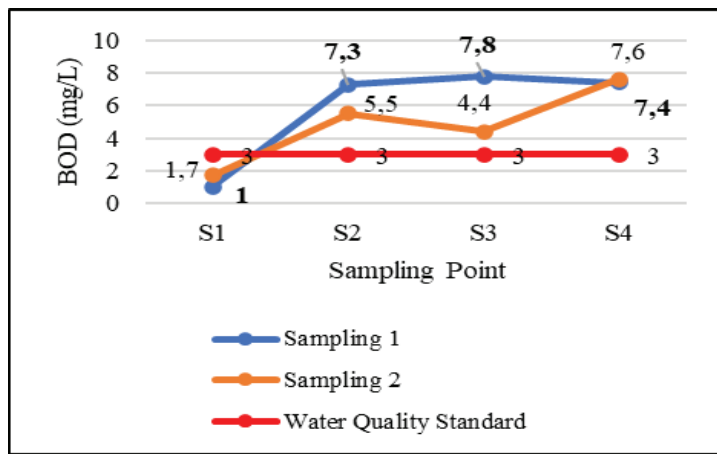

Fig. 14. Biochemical oxygen demands (BOD) in Parangan River based on the laboratory analysis of samples collected in duplicate at four sampling points

Total suspended solids (TSS) measure particles that are larger than $>1 \mu \mathrm{m}$ in diameter, floating or drifting in the water, water-insoluble and are retained if passed through a $0.45 \mu \mathrm{m}$ filter paper [1]. The laboratory analysis results showed TSS in the range of $1-5 \mathrm{mg} / \mathrm{L}$ (Fig. 15). Because the permissible maximum TSS is 50 $\mathrm{mg} / \mathrm{L}$ [7], the water in the Parangan River can be used for class II purposes. Furthermore, the low TSS indicates that the liquid waste does not contain solids that affect water quality [18].

Another parameter of water contamination by the liquid waste from the tofu industry is ammonia. The laboratory analysis results showed that the ammonia levels of the samples were $<0.0062-0.4998 \mathrm{mg} / \mathrm{L}$ (Fig. 16) or high because of the liquid waste outlets at the sampling site. Government Regulation Number 82 of 2001 does not include the upper limit values for ammonia presence in rivers used for class II purposes. However, because of its inert toxicity, the total ammonia found in waters should not exceed $0.2 \mathrm{mg} / \mathrm{L}$ [16]. High ammonia presence can interfere with the growth of aquatic biota [18].

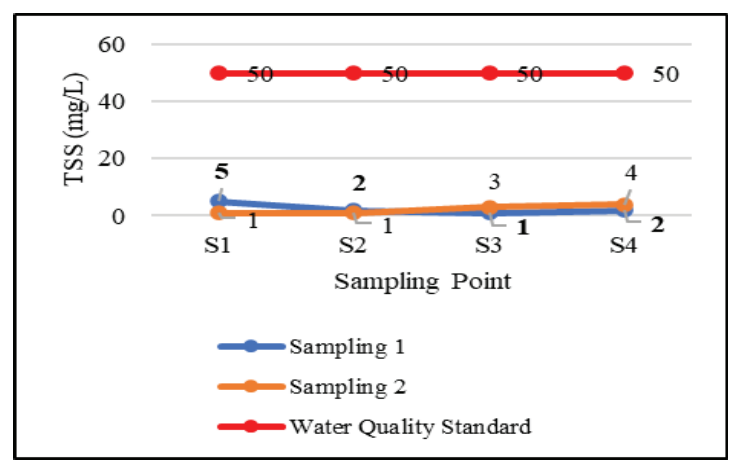

Fig. 15. Total suspended solids (TSS) in Parangan River based on the laboratory analysis of samples collected in duplicate at four sampling points

Dissolved oxygen (DO) represents the amount of oxygen produced in photosynthesis (by aquatic biota and microorganisms) and the entry of air into water [19]. Higher DO indicates better water quality. The DO of the samples varied from 4.4 to $8.2 \mathrm{mg} / \mathrm{L}$ (Fig. 17), which meet the stipulated lower limit value of at least $4 \mathrm{mg} / \mathrm{L}$ [7]. However, DO levels were found to decrease from point $\mathrm{S} 1$ to $\mathrm{S} 4$, meaning that the water quality worsens further downstream. This is because the liquid waste disposed of without pre-treatment contained a significant amount of organic matter [24].

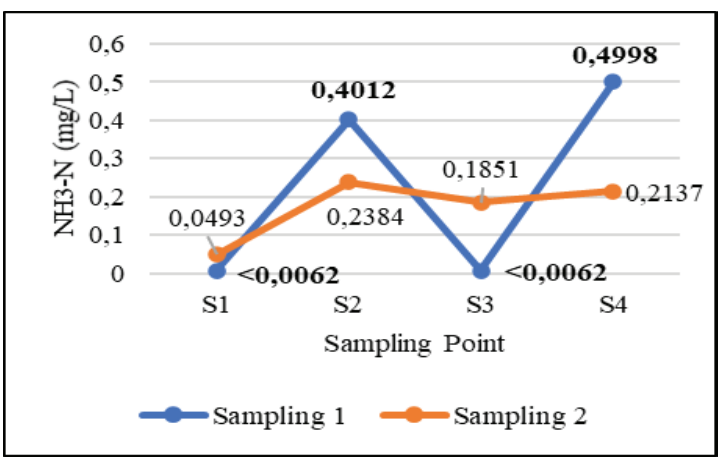

Fig. 16. Total ammonia contents $\left(\mathrm{NH}_{3}-\mathrm{N}\right)$ in Parangan River based on the laboratory analysis of samples collected in duplicate at four sampling points

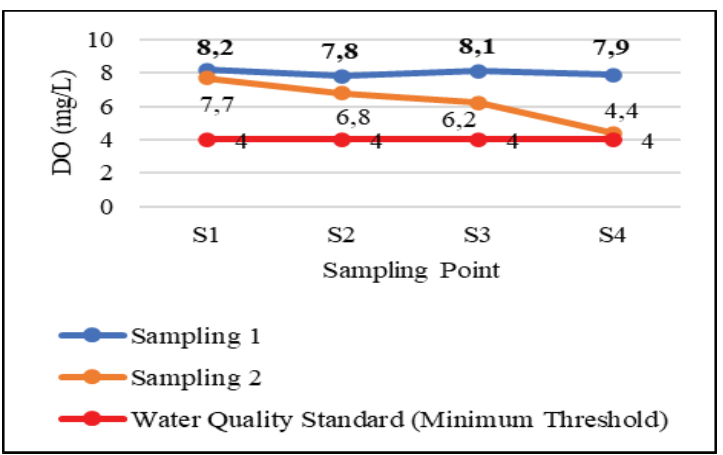

Fig. 17. Dissolved oxygen (DO) levels in Parangan River based on the laboratory analysis of samples collected in duplicate at four sampling points 
The water quality in the Parangan River showed a fluctuating pattern at each sampling point. However, based on the analysis results of the duplicate samples, there was a decreasing trend in quality from the first to the last points downstream. Some influencing factors included the liquid waste disposed of to the river and the river discharge. If left uncontrolled, this water contamination can only become worse. The same case has been identified at Muara Murong River in Jombang (East Java, Indonesia) and Tikala River in Manado (North Sulawesi, Indonesia), whose water qualities deteriorate because of the continuous disposal of untreated waste to these rivers $[2,18]$.

\subsection{River Water Quality Status}

Here, status defines and categorises water quality conditions into good-quality to polluted within a particular length of time by comparing the parameters with the specified water quality standards [7]. Based on the direct measurements in the field and the laboratory analysis results, the parameter values or classes at $\mathrm{S} 1$ meet the standards, meaning that the water at this sampling point has good quality. On the contrary, some parameters at S2, S3 and S4 were outside their accepted range, indicating slightly polluted water. These three points represent river segments that continuously receive liquid waste from the tofu-making process; hence, poorer water quality conditions than S1 (upstream of the waste outlet).

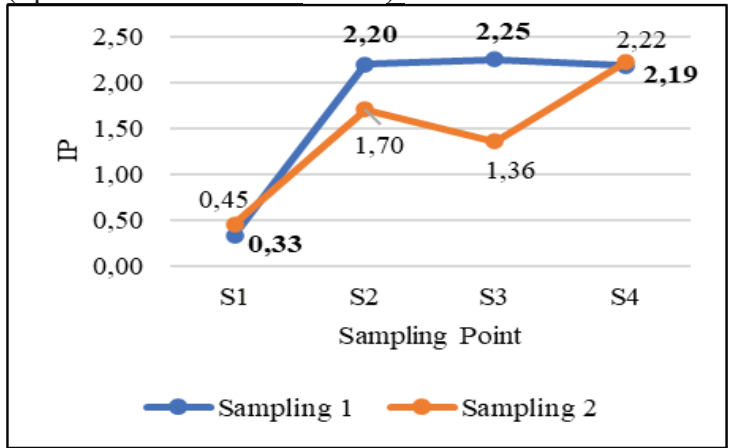

Fig. 18. The water quality status of the Parangan River based on the Pollution Index

Similarly, the Pollution Index (PI) values of S2, S3 and S4 (higher than 1.70) were lower than S1 $(0.33-0.43)$ (Fig. 18). This finding confirms that the untreated liquid waste discharged at point S2 decreases river water quality. The PI values can change if the observed water quality parameters increase [20]. However, PI varies not only according to the waste input but also flow velocity. Severe contamination occurs in a river segment with fast flows, whereas slight pollution is found in a river segment with low velocity. In this context, low stream velocity allows an effective contact between the substrate and microorganisms, while high stream velocity leads to shorter contact and less optimal self-purification [21].

\subsection{Total Maximum Daily Load}

Pollution load is the amount of a polluting element that a water body, e.g., a river, carries at a given time [7]. In this research, the pollution load calculation produced the total maximum daily load (TMDL) at S4 (Table 4). The results showed that $\mathrm{BOD}$, as an indicator of pollution loads, was the only parameter at S4 that exceeded the specified upper limit in class II water quality [7]. Other parameters like $\mathrm{pH}$, temperature, COD, TSS, $\mathrm{NH}_{3}-\mathrm{N}$ and DO were still below the TMDL. The first sample at S4 (S4-1) showed that the COD level was below but close to the specified threshold. For this reason, it is imperative that treatments and preventive strategies be enforced to lower any parameters that nearly exceed their respective upper limit values.

Table 4. The pollution loads in the Parangan River

\begin{tabular}{|c|c|c|c|c|c|c|c|c|}
\hline $\begin{array}{l}\text { Sampling } \\
\text { Points }\end{array}$ & $\begin{array}{c}\text { Disch } \\
\text { arge } \\
\left(\mathrm{m}^{3} / \mathrm{s}\right)\end{array}$ & pH & $\begin{array}{c}\text { Temp } \\
\cdot \\
\left({ }^{\circ} \mathrm{C}\right)\end{array}$ & $\begin{array}{c}\text { COD } \\
\text { (mg/ } \\
\text { L) }\end{array}$ & $\begin{array}{c}\text { BO } \\
\text { D } \\
(\mathbf{m g} \\
/ \mathbf{L})\end{array}$ & $\begin{array}{c}\text { TSS } \\
\text { (mg/L } \\
\text { ) }\end{array}$ & $\begin{array}{l}\mathrm{NH}_{3}-\mathrm{N} \\
(\mathrm{mg} / \mathrm{L})\end{array}$ & $\begin{array}{c}\text { DO } \\
\text { (mg/L } \\
\text { ) }\end{array}$ \\
\hline S1-1* & 0.98 & 7.22 & 27.1 & 10.6 & 1 & 5 & 0.0062 & 8.2 \\
\hline S2-1 & 1.44 & 6.52 & 26.6 & 33 & 7.3 & 2 & 0.4012 & 7.8 \\
\hline S3-1 & 1.88 & 6.77 & 26.4 & 17.6 & 7.8 & 1 & 0.0062 & 8.1 \\
\hline S4-1 & 4.30 & 6.79 & 26.63 & $\begin{array}{c}21.1 \\
7\end{array}$ & $\begin{array}{c}6.0 \\
8\end{array}$ & 2.25 & 0.1387 & 8.02 \\
\hline S1-2* & 0.98 & 7.11 & 26.7 & 14.3 & 1.7 & 1 & 0.0493 & 7.7 \\
\hline S2-2 & 1.44 & 6.98 & 26.3 & 13.9 & 5.5 & 1 & 0.2384 & 6.8 \\
\hline S3-2 & 1.88 & 6.92 & 26.5 & 12.1 & 4.4 & 3 & 0.1851 & 6.2 \\
\hline S4-2 & 4.30 & 6.98 & 26.48 & 13.20 & 4.15 & 1.87 & 0.1720 & 6.74 \\
\hline $\begin{array}{l}\text { Water } \\
\text { Quality } \\
\text { Standards }\end{array}$ & - & 6-9 & $\begin{array}{c}3 \\
\text { (devia } \\
\text {-tion) }\end{array}$ & 25 & 3 & 50 & - & 4 \\
\hline
\end{tabular}

Pollution load is inseparable from natural conditions and human activities in the vicinity. High BOD is associated with the liquid waste generated by the tofu industry that contains high organic matter. The level of BOD as an indicator of pollution load depends on the amount of the liquid waste disposed of to the river.

The TMDL calculation produces the maximum permissible amount of waste or pollutants present in the river. This way, the water body can self-purify optimally, and relevant authorities can perform proper river management and immediate restoration of impaired waters where this maximum amount has been exceeded [22]. Overall, the TMDL in the Parangan River is within the safety buffer because the number of parameters that exceeded the maximum pollution load is fewer than those that did not.

\section{Conclusion}

The liquid waste quality generated by the tofu industry has exceeded the specified limits for temperature, $\mathrm{pH}$, COD, BOD, TSS and ammonia contents described in Provincial Regulation No. 5/2012. The water in the Parangan River has also exceeded the upper limit values of $\mathrm{BOD}$ and $\mathrm{COD}$ in class II water quality standards (Government Regulation Number 82 of 2001). Compared with the river segment upstream of the waste outlet (S1), the segments downstream (S2-4) have higher TSS and ammonia content and lower DO, indicating contamination by the liquid waste. 
In terms of status, $\mathrm{S} 1$ has good-quality water, while S2, S3 and S4 are slightly polluted. Parangan River can accommodate pollution loads (as evident from $\mathrm{pH}$, temperature, $\mathrm{COD}, \mathrm{TSS}, \mathrm{NH}_{3}-\mathrm{N}$ and $\mathrm{DO}$ ) while still meeting the specified water quality standards, except for those indicated by high BOD levels.

\section{Acknowledgement}

The authors would like to thank Universitas Gadjah Mada for funding this research through the Final Project Recognition Grant (Hibah Rekognisi Tugas Akhir) scheme for the fiscal year 2021. The authors are also grateful to the Faculty of Geography, Universitas Gadjah Mada, for providing the opportunity to conduct this research.

\section{References}

1. Effendi, H., Telaah Kualitas Air Bagi Pengelolaan Sumber Daya dan Lingkungan Perairan. Kanisius, Yogyakarta (2003)

2. R. D. Sandi., Analisis Kualitas Air dan Distribusi Limbah Cair Industri Tahu Di Sungai Murong Kecamatan Jogoroto Kabupaten Jombang, Swara Bhumi., 5(9), 59-66 (2019)

3. H. Husni, and M. Esmiralda., Uji Toksisitas Akut Limbah Cair Industri Tahu Terhadao Ikan Mas (Cyprinus carpio Lin) (Studi Kasus: Limbah Cair Industri Tahu "SUPER", Padang), Bachelor Thesis. Faculty of Engineering, University of Andalas, Padang (2011)

4. C. Asdak., Hidrologi dan Pengelolaan Daerah Aliran Sungai. Gadjah Mada University Press, Yogyakarta (2002)

5. L. R. Mubarok., Kajian Karakteristik Pencemar Bagi Hulu Sungai Belik, Daerah Istimewa Yogyakarta, Bachelor Thesis. Faculty of Geography, Universitas Gadjah Mada, Yogyakarta (2018)

6. Anonymous, Peraturan Daerah Jawa Tengah Nomor 5 Tahun 2012 tentang Baku Mutu Air Limbah, Sekretariat Negara, Jawa Tengah, (2012)

7. Anonymous, Peraturan Pemerintah Nomor 82 Tahun 2001 tentang Pengelolaan Kualitas Air dan Pengendalian Pencemaran Air. Sekretariat Negara, Jakarta, (2001)

8. Nurhasan, and B. B. Pramudyanto., Pengolahan Air Buangan Tahu. Yayasan Bina Karta Lestari dan Wahana Lingkungan Hidup Indonesia, Semarang (1991)

9. BPPT., Teknologi Pengolahan Limbah TahuTempe Dengan Proses Biofilter Anaerob Aerob. Laporan Kegiatan. Kelompok Teknologi Pengolahan Air Bersih dan Limbah Cair, Jakarta (1997)

10. D. D. Kesuma., Pengaruh Limbah Industri Tahu Terhadap Kualitas Air Sungai di Kabupaten Klaten. Bachelor Thesis. Faculty of Geography, Universitas Gadjah Mada, Yogyakarta (2012)

11. R. P. Dewa., and S. Idrus., Identifikasi Cemaran
Air Limbah Industri Tahu Di Kota Ambon. Majalah Biam, 13(2), 11-15, (2017)

12. E. Wiryani., Analisis Kandungan Limbah Cair Pabrik Tempe. Lab. Ekologi dan Biosistematik Jurusan Biologi FMIPA Universitas Diponegoro, Semarang, (2007)

13. C. E. Boyd., Water Quality in Warmwater Fish Ponds. Fourth Printing. Auburn University Agricultural Experiment Station Alabama, USA, (1988)

14. C. E. Boyd., Water Quality: An Introduction, 3rd ed. Springer Nature Switzerland, Cham, (2020)

15. E. K. Sari., and O.E. Wijaya., Penentuan Status Mutu Air dengan Metode Indeks Pencemaran dan Strategi Pengendalian Pencemaran Sungai Ogan Kabupaten Ogan Komering Ulu. J. Ilmu Lingkungan, 13(3), 486-491, (2019)

16. M. Widyastuti, and E. Haryono, Water Quality Characteristics of Jonge Telaga (Doline Pond) as Water Resources for the People of Semanu District Gunungkidul Regency. Indonesian Journal of Geography, 48(2), 157-167, (2016)

17. D. Mardhia., and V. Abdullah., Studi Analisis Kualitas Air Sungai Brangbiji Sumbawa Besar. $J$. Biologi Tropis, 18(2), 182-189, (2018)

18. Sepriani, J. Abidjulu., and H. S. J. Kolengan., Pengaruh Limbah Cair Industri Tahu Terhadap Kualitas Air Sungai Paal 4 Kecamatan Tikala Kota Manado. Chem. Prog., 9(1), 29-33, (2016)

19. H. Effendi, R. Seroja, and S. Hariyadi., Response Surface Method Application In Tofu Production Liquid Waste Treatment. Indones. J. Chem., 19(2), 298 - 304, (2019)

20. Y. Martinus, W. Astono, and D. Hendrawan., IOP Conf. Ser.: Earth Environ. Sci. 106012022 (2018)

21. A. Suriadikusumah, O. Mulyani, R. Sudirja, E. T. Sofyan, M. H. R. Maulana, and A. Mulyono., Analysis Of The Water Quality At Cipeusing River, Indonesia Using The Pollution Index Method, Acta Ecologica Sinica, 41(3), 177-182, (2021)

22. Y. Rahayu, I. Juwana, and D. Marganingrum., Kajian Perhitungan Beban Pencemaran Air Sungai Di Daerah Aliran Sungai (DAS) Cikapundung Dari Sektor Domestik. Jurnal Rekayasa Hijau, 2(1), $61-71,(2018)$

23. S. Y. Saragih., Evaluasi Kualitas Air Sungai Bukit Tujuh di Desa Bukit Tujuh Torgamba Kabupaten Labuhanbatu Selatan, Skripsi. Fakultas Ilmu Sosial Universitas Negeri Medan, Medan (2015)

24. A. Azwar., Soemarno, and M. Purnomo., Kajian Kualitas Air dan Status Mutu Air Sungai Metro di Kecamatan Sukun Kota Malang. Jurnal Bumi Lestari, 13(2), 265 - 274, (2013) 